\title{
Effect of first lactation milk yield on efficiency of cows in herds with different production levels
}

\author{
ANNA SAWA and SYLWIA KRĘŻEL-CZOPEK \\ Department of Cattle Breeding, Faculty of Animal Breeding and Biology, University of Technology and Life \\ Sciences, Bydgoszcz, Poland
}

\begin{abstract}
Lifetime performance was analysed in 6981 Black and White cows with different proportion of Holstein Friesian inheritance from the active population in the KujawskoPomorskie province according to first lactation yield. It was shown that from the viewpoint of lifetime efficiency, the optimum milk yield of first calvers depends on the milk yield level of the herd. In herds with $\leq 5000 \mathrm{~kg}$ milk production, the best efficiency was shown by the cows that produced $6001-7000 \mathrm{~kg}$ milk as first calvers. A decrease in lifetime milk yield, reduced life span and length of productive life, and lower fertility should be taken into account for more efficient first calvers. In herds with 5 000-6 500 and $>6500 \mathrm{~kg}$ milk production, lifetime milk yield and milk yield per day of (productive) life increased with increased first lactation milk yield, while fertility deteriorated.
\end{abstract}

Keywords: cow, first lactation, milk yield, lifetime performance, length of productive life

\section{Zusammenfassung}

\section{Einfluss der Erstlaktationsleistung auf die Lebensleistung von Kühen in Herden mit unterschiedlichem Leistungsniveau}

Untersucht wurde die Lebensleistung von 6981 schwarzbunten Kühen mit unterschiedlichen Holstein-Friesian-Anteil aus der Kujawsko-Pomorskie Provinz unter besonderer Berücksichtigung der Erstlaktationsleistung. Es zeigte sich, dass unter dem Gesichtspunkt der Lebensleistung das Optimum der Erstlaktationsleistung vom Niveau der Herdenleistung abhängig war. In Herden mit einer Durchschnittsleistung von $\leq 5000 \mathrm{~kg}$ Milch ergab sich eine beste Lebensleistung bei Kühen welche $6001-7000 \mathrm{~kg}$ Milch in der ersten Laktation erbrachten. Lag in diesen Betrieben die Erstlaktationsleistung über $7000 \mathrm{~kg}$ wurde eine geringere Lebensleistung, Nutzungsdauer und geringere Fruchtbarkeit nachgewiesen. In Herden mit 5000-6500 kg sowie Herden mit $>6500 \mathrm{~kg}$ Milch war die Lebensleistung sowie die tägliche Milchleistung mit einer hohen Erstlaktationsleistung jedoch einer Verschlechterung der Fruchtbarkeit und geringeren Anzahl Kalbungen verbunden.

Schlüsselwörter: Kuh, Erstlaktation, Milchertrag, Lebensleistung, Nutzungsdauer 


\section{Introduction}

The milk yield of first calvers from the active population in Poland has considerably increased in recent years (4 $595 \mathrm{~kg}$ milk in 1999 vs $6350 \mathrm{~kg}$ milk in 2006: CSHZ 2000, $\mathrm{KCHZ} \mathrm{2007).} \mathrm{First} \mathrm{lactation} \mathrm{is} \mathrm{considered} \mathrm{as} \mathrm{test} \mathrm{lactation} \mathrm{because} \mathrm{the} \mathrm{cows'} \mathrm{body} \mathrm{is} \mathrm{still}$ developing. First lactation yield gains in importance in view of a long-term tendency towards shortening the length of productive life in cows (JUSZCZAK et al. 1994, SAWA 1998, REKLEWSKI et al. 2004). JUSZCZAK et al. (1994), who analysed the tendency towards shortened length of cows' productive life in terms of compensation for rearing costs, reported that efforts are made in Germany for the milk yield of first lactation cows to reach a level compensating for these costs, i.e. approx. $6000 \mathrm{~kg}$ of milk. However, the high first lactation milk yield may negatively affect the health of young, developing cows and result in the earlier elimination of cows from the herd (JUSZCZAK et al. 1994, GNYP et al. 1999, JANUŚ \& BORKOWSKA 2004). Moreover with increasing milk yield, fertility results declined (SOELKNER et al. 2000, BIELFELDT et al. 2004). Different studies also indicated an antagonistic relationship between higher milk yield and reproductive performance (NEBEL \& McGILLARD 1993, SEELAND \& HENZE 2003). In addition, fertility and udder health problems are one of the most significant problems affecting commercial milk production (HINRICHS et al. 2006).

In breeding practice, growing attention is given to the improvement of functional traits that determine the efficiency of rearing dairy cattle (BAUMUNG et al. 2001, HARDER et al. 2004). Among these, important roles are played by fertility, life span, length of productive life, and amount of milk per day of (productive) life (SWALVE 2003). Another important factor is the relation between the cows' length of productive life and life span, which reflects the proportion of the non-productive period in the cows' lifetime (GNYP et al. 1999, SAWA 1998).

The aim of the study was to analysis of effect of first lactation milk yield on efficiency of cows in herds with different production levels.

\section{Material and methods}

The study was carried out based on information from the SYMLEK database. The analysis included 6981 Black-and-White cows with different proportions of Holstein-Friesian inheritance, representing the active population of the Kujawsko-Pomorskie province. The cows first calved between 1 June 1998 and 31 May 1999 and were culled by the final day of data collection (31 December 2005). Data on the dates of successive calvings and milk yield in successive full lactations were collected for each cow. These were used to determine lifetime efficiency: lifetime milk yield (total efficiency of milk in period of whole life), length of life (interval since day of birth till day of cull), length of productive life (interval since day of first calving till day of cull), the relation between the length of productive life and life span (days of productive life -100/days of life), milk yield per day of (productive) life, calving interval (OMW) and number of calvings.

Least squares analysis of variation (SAS 2004) was used to evaluate the effect of first lactation milk yield ( $\leq 5000 \mathrm{~kg}, 5001-6000,6001-7000$ and $>7000)$ within different herd 
production levels (low: $\leq 5000 \mathrm{~kg}$, medium: $5001-6500 \mathrm{~kg}$, high: $>6500 \mathrm{~kg}$ ) on lifetime efficiency of the cows.

The statistical analisis was based on the following linear model (SAS 2004):

$$
Y=\mu+a_{i}+b_{j}+(a b)_{i j}+e_{i j k}
$$

where is $\mu$ the overall mean; $a_{i}$ the effect of first lactation milk yield ( $\leq 5000,5001-6000$, $6001-7000$ and $>7000 \mathrm{~kg}$ ); $b_{j}$ the effect of herd production level (low: $\leq 5000 \mathrm{~kg}$, medium: $5001-6500 \mathrm{~kg}$, high: $>6500 \mathrm{~kg})$; $(a b)_{i j}$ the interaction between first lactation milk yield and herd production level and $e_{i j k}$ the random error.

Differences between the means of particular traits were estimated using Scheffe's test. The CORR PEARSON procedure (SAS 2004) was used to calculate the simple correlation coefficients between first lactation milk yield and parameters of lifetime efficiency. Using chi $^{2}$ test (SAS 2004), the proportion of cows in first lactation milk yield and herd milk yield subgroups was analysed.

\section{Results}

Most cows (41\%) were used in herds with medium production levels and fewest cows $(23 \%)$ in herds with high production levels (Table 1). Analysis of the cows according to their first lactation milk yield showed that almost $48 \%$ failed to produce $5000 \mathrm{~kg}$ milk. The $6000 \mathrm{~kg}$ milk level was exceeded by $32 \%$ of first calvers, including $19 \%$ first calvers with $>7000 \mathrm{~kg}$ milk production. The increase in herd milk yield level from $\leq 5000 \mathrm{~kg}$ to $>6500 \mathrm{~kg}$ was paralleled by a 6-fold decrease (from 76 to 12\%) in the proportion of first calvers with $\leq 5000 \mathrm{~kg}$ milk production and by a 15 -fold increase (from 3.5 to $53 \%$ ) in the proportion of age mates with $>7000 \mathrm{~kg}$ milk production.

The increase in average lifetime milk yield was paralleled by the increase in first lactation milk yield, with a particularly high increase between the $\leq 5000 \mathrm{~kg}$ and 5001 $6000 \mathrm{~kg}$ groups (Table 2). The results obtained were confirmed by the coefficient of correlation calculated $\left(r=0.439^{* *}\right.$, Table 3$)$. This shows that the lifetime milk yield of a cow can be predicted based on the first lactation.

The increase in the milk yield of first calvers, especially beyond $5000 \mathrm{~kg}$ milk production, was paralleled by improved lifetime efficiency measured by average milk yield per day of (productive) life, life span and length of productive life, although the last two parameters decreased when the first lactation milk yield exceeded $7000 \mathrm{~kg}$ milk (Table 2). The coefficients of correlation calculated between first lactation milk yield and life span and length of productive life were positive and highly significant but low (approx. 0.2, Table 3).

The increased milk yield of first calvers was paralleled by improved lifetime efficiency measured by the average relation between theb length of productive life and life span, with a particularly marked increase between the $\leq 5000 \mathrm{~kg}$ and $5001-6000 \mathrm{~kg}$ milk groups (Table 2).

As the average life span and length of productive life increased with increasing first lactation milk yield, the average number of calvings did not increase (Table 2). This resulted from the fact that fertility of the cows decreased with their increasing first 
lactation milk yield. The average calving interval increased proportionately to the milk yield of first calvers: by 23 days for the milk yield increase from $\leq 5000 \mathrm{~kg}$ to $5001-6000$ $\mathrm{kg}$ and by as many as 71 days for the milk yield increase from $6001-7000 \mathrm{~kg}$ to $>7000 \mathrm{~kg}$. The correlation between first lactation milk yield and length of calving interval was positive and highly significant $\left(r=0.496^{* *}\right.$, Table 3$)$.

The results given in Table 2 show that the best first lactation milk yield in terms of lifetime efficiency varies according to herd production level. In herds with a low production level, the best efficiency was found in cows that produced $6001-7000 \mathrm{~kg}$ milk as first calvers, whereas reduced lifetime milk yield and much poorer fertility was observed in first calvers with milk yield above $7000 \mathrm{~kg}$. In herds with medium and high production levels, the increase in the milk yield of first calvers was paralleled by increased lifetime yield and yield per day of (productive) life and reduced fertility and number of calvings. The life span and length of productive life also decreased when the milk yield of first calvers exceeded $6000 \mathrm{~kg}$ (herds with a medium production level) or $7000 \mathrm{~kg}$ (herds with the highest production level).

It was found that the average length of calving interval decreased with increasing herd production level and increased with increasing milk yield of first calvers (Table 2). As a result, calving interval was the shortest (377 days) in the cows that produced $\leq 5000 \mathrm{~kg}$ milk as first calvers and were used in herds with the highest production level. Calving interval was the longest (587 days) in the cows that produced $>7000 \mathrm{~kg}$ milk as first calvers and were used in herds with the lowest production level. The negative effect of the high milk yield on subsequent fertility is confirmed by a modest correlation $\left(r=0.49^{* *}\right.$, Table 3).

\section{Discussion}

Given the cows' rearing costs of $6000 \mathrm{~kg}$ milk (JUSZCZAK et al. 1994), it should be stated that in the analysed population, $32 \%$ of the cows reached first lactation milk yields that compensated for these costs. According to JUSZCZAK et al. (1994), the cows whose first lactation milk yield exceeded $6000 \mathrm{~kg}$ milk accounted for almost $30 \%$ of the population, but their study focused on top Polish herds and accounted for the period 1971-1991.

First lactation milk yield gains in importance in view of the relatively short period of cows' productive life found in the present study (average of 3.19 years per cow). Better production efficiency of the cows achieving higher first lactation milk yield was also reported by other authors (JUSZCZAK et al. 1994, GNYP et al. 1999, BRZOZOWSKI et al. 2003, JANUŚ \& BORKOWSKA 2004). It is significant, however, that in the studies of other authors, lifetime efficiency of the cows improved when the milk yield of first calvers reached $6000 \mathrm{~kg}$ (GNYP et al. 1999) or $8000 \mathrm{~kg}$ (JUSZCZAK et al. 1994).

In the present study, the cows that exceeded $7000 \mathrm{~kg}$ milk yield as first calvers had an average lifetime production of $9564 \mathrm{~kg}$ more milk (a difference of approx. 176\%) compared to their age mates that produced up to $5000 \mathrm{~kg}$ milk in the first lactation (Table 2). The differences in lifetime yield varied according to the milk yield level in the herd in which the cows were used and were $134 \%$ for herds with low production levels and as much as $260 \%$ for herds with high production levels. According to JUSZCZAK et al. (1994) and GNYP et al. (1999), the optimum first lactation milk yield level from the viewpoint of milk 
use efficiency varies according to management conditions and herd milk yield level. The decrease in the lifetime milk yield of high-yielding cows (with first lactation milk yield of $>7000 \mathrm{~kg}$ ), found in the present study in herds with low production levels is evidence that environmental conditions failed to meet the production needs of the cows.

Analysis of the relationship between the milk yield and fertility of cows takes on special significance because current cattle farming trends provide for a systematic increase in milk yield. NEBEL and McGILLARD (1993) reported that selection of cows for milk yield increases the concentration of somatotropin and prolactin, which stimulate milk secretion, while reducing the concentration of insulin that acts antagonistically towards the above hormones but stimulates the growth of ovarian follicles. As a consequence, cows with higher milk yields calve later and require a greater number of inseminations needed for successful conception (OUWELTJES et al. 1996). According to SWANSON (1989), in high-yielding cows the mammary gland has priority over the reproductive system. In the present study, the fertility of cows was poor and the average calving interval increased from 387 days to 516 days with increasing first lactation milk yield. It was also shown that within the milk yield levels of first calvers, especially in the groups with 6001-7 000 and $>7000$ kg milk yield, fertility improved with increased milk yield level in the herd (Table 2). Likewise, JANUŚ \& BORKOWSKA (2004) showed differences in the length of calving interval according to first lactation milk yield. Despite the negative correlation between milk yield and reproductive parameters, some researchers hold that the increase in milk yield exceeds the veterinary costs associated with treatment of animals (DUNKLE et al. 1994).

When analysing the reproductive efficiency of cows based on average number of calvings, it was found (in agreement with JUSZCZAK et al. 1994) that it decreased with first lactation milk yield increasing above $5000 \mathrm{~kg}$, due to the lengthening of calving intervals. The cows that produced $\leq 5000 \mathrm{~kg}$ milk as first calvers gave birth to the greatest number of calves during their lifetime, when they were used in herds with low milk yield levels. For cows that produced $6001-7000$ and $>7000 \mathrm{~kg}$ milk as first calvers, the number of calvings increased with increasing milk yield level in the herd, which confirms very good cow management and production conditions in these herds.

The length of productive life is a factor determining the economic results of milk production and affects the extent of production and breeding progress (ZIEMIŃSKI \& HIBNER 1991, SWALVE 2003). The average length of productive life obtained in the present study (3.19 years) is higher (and more favourable) than the results obtained by REKLEWSKI et al. (2004), although it is considered too short because, as reported by KANCER et al. (2001), from the economic point of view the utilization of cows should last at least four lactations to be profitable. Considering the short life span of cows, it can be stated that high first lactation milk yield has a positive effect on lifetime productivity. It was shown, however, that excessive milk yield of first calvers (over $7000 \mathrm{~kg}$ ) reduces the length of productive life, while JUSZCZAK et al. (1994) point out that the length of cows' productive life decreases with first lactation milk yield exceeding $5000 \mathrm{~kg}$. JANUŚ \& BORKOWSKA (2004) showed no significant differences between the cows' life span and length of productive life, but observed that these periods decreased with increasing first lactation milk yield (cows producing over $6000 \mathrm{~kg}$ milk in their first lactation were 
characterized by the shortest life span and length of productive life). BRZOZOWSKI et al. (2003) reported that first lactation milk yield has no effect on the length of cows' productive life in the herd. Analysis of the potential for length of productive life in herds with different production levels (Table 2) showed that regardless of the herd production level, by far the shortest period of use was characteristic of the cows that produced $\leq 5000 \mathrm{~kg}$ milk as first calvers. In herds with low and medium production levels, cows that produced $6001-7000 \mathrm{~kg}$ milk as first calvers were characterized by the longest use, while in herds with medium production levels, cows that produced $5001-6000 \mathrm{~kg}$ milk as first calvers were used the longest.

Table 1

Effect of first lactation milk yield and herd productivity level on lifetime efficiency

Erstlaktationsleistung, Herdenleistung und Nutzungsdauer

\begin{tabular}{|c|c|c|c|c|c|c|}
\hline \multirow{2}{*}{$\begin{array}{l}\text { Parameters of } \\
\text { cows' lifetime } \\
\text { performance }\end{array}$} & \multirow{2}{*}{$\begin{array}{c}\text { Herd yield } \\
\text { level (kg milk) }\end{array}$} & \multicolumn{4}{|c|}{ First lactation milk yield (kg milk) } & \multirow{2}{*}{$\begin{array}{c}\text { Significance } \\
\text { between the } \\
\text { groups }\end{array}$} \\
\hline & & $\begin{array}{c}1 \\
\leq 5000 \\
\end{array}$ & $\begin{array}{c}2 \\
5001-6000 \\
\end{array}$ & $\begin{array}{c}3 \\
6001-7000 \\
\end{array}$ & $\begin{array}{c}4 \\
>7000 \\
\end{array}$ & \\
\hline \multirow{4}{*}{$\begin{array}{l}\text { Lifetime yield } \\
\text { (kg milk) }\end{array}$} & $\leq 5000$ & 13171 & 16728 & 18557 & 17708 & $1-2,3^{*}$ \\
\hline & $5001-6500$ & 14167 & 20207 & 20221 & 21381 & $1-2,3,4^{* *}$ \\
\hline & $>6500$ & 10590 & 20577 & 24794 & 27531 & $1-2,3,4^{* *}$ \\
\hline & average & 12643 & 19157 & 21190 & 22207 & - \\
\hline \multirow{4}{*}{$\begin{array}{l}\text { Lifetime } \\
\text { (years) }\end{array}$} & $\leq 5000$ & 5.44 & 5.85 & 6.06 & 5.88 & - \\
\hline & $5001-6500$ & 5.03 & 5.84 & 5.74 & 5.83 & $1-2,3,4^{* *}$ \\
\hline & $>6500$ & 4.09 & 5.40 & 5.80 & 5.77 & $1-2,3,4^{* *}$ \\
\hline & average & 4.85 & 5.70 & 5.87 & 5.82 & - \\
\hline \multirow{4}{*}{$\begin{array}{l}\text { Length of } \\
\text { productive life } \\
\text { (years) }\end{array}$} & $\leq 5000$ & 3.07 & 3.47 & 3.70 & 3.46 & - \\
\hline & $5001-6500$ & 2.76 & 3.56 & 3.42 & 3.49 & $1-2,3,4^{* *}$ \\
\hline & $>6500$ & 1.79 & 3.10 & 3.47 & 3.42 & $1-2,3,4^{* *}$ \\
\hline & average & 2.54 & 3.38 & 3.54 & 3.46 & \\
\hline \multirow{4}{*}{$\begin{array}{l}\text { Length of } \\
\text { productive life } \\
\text { to life span (\%) }\end{array}$} & $\leq 5000$ & 50.20 & 56.11 & 58.54 & 57.08 & $1-2^{* *}, 1-3^{*}$ \\
\hline & $5001-6500$ & 47.88 & 57.53 & 56.66 & 57.58 & $1-2,3,4^{* *}$ \\
\hline & $>6500$ & 33.37 & 53.64 & 56.62 & 56.68 & $1-2,3,4^{* *}$ \\
\hline & average & 43.82 & 55.76 & 57.27 & 57.11 & - \\
\hline \multirow{4}{*}{$\begin{array}{l}\text { Yield per day } \\
\text { of life } \\
\text { (kg milk) }\end{array}$} & $\leq 5000$ & 5.80 & 7.29 & 7.99 & 7.96 & $1-2,3,4^{* *}$ \\
\hline & $5001-6500$ & 6.63 & 8.88 & 9.10 & 9.58 & $1-2,3,4^{* *}$ \\
\hline & $>6500$ & 5.42 & 9.67 & 10.99 & 12.40 & $1-2,3,4^{* *}$ \\
\hline & average & 5.95 & 8.61 & 9.36 & 9.98 & \\
\hline \multirow{4}{*}{$\begin{array}{l}\text { Yield per day } \\
\text { of utilization } \\
\text { (kg milk) }\end{array}$} & $\leq 5000$ & 11.45 & 12.81 & 13.56 & 13.86 & $1-2,3,4^{* *}$ \\
\hline & $5001-6500$ & 13.70 & 15.35 & 15.97 & 16.56 & $1-2,3,4^{* *}$ \\
\hline & $>6500$ & 17.27 & 17.95 & 19.30 & 21.75 & $1-3,4^{* *}$ \\
\hline & average & 14.14 & 15.37 & 16.28 & 17.39 & - \\
\hline \multirow{4}{*}{$\begin{array}{l}\text { Number of } \\
\text { calvings }\end{array}$} & $\leq 5000$ & 3.22 & 3.24 & 3.25 & 2.73 & - \\
\hline & $5001-6500$ & 3.02 & 3.60 & 3.29 & 3.05 & $1-2^{* *}$ \\
\hline & $>6500$ & 2.27 & 3.38 & 3.55 & 3.22 & $1-2,3,4^{* *}$ \\
\hline & average & 2.84 & 3.41 & 3.36 & 3.00 & \\
\hline \multirow{4}{*}{$\begin{array}{l}\text { Calving interval } \\
\text { (mean, days) }\end{array}$} & $\leq 5000$ & 397 & 442 & 495 & 587 & $1-2,3,4^{* *}$ \\
\hline & $5001-6500$ & 387 & 403 & 435 & 504 & $1-2^{*}, 1-3,4^{* *}$ \\
\hline & $>6500$ & 377 & 386 & 406 & 456 & $1-4^{* *}$ \\
\hline & average & 387 & 410 & 445 & 516 & - \\
\hline
\end{tabular}

* differences statistically significant at $P \leq 0.05, \quad * *$ differences statistically significant at $P \leq 0.01$ 
The analysis leads to a conclusion that the optimum level of milk yield in first calvers in terms of milk production efficiency varies according to herd production level, which serves as a measure of the quality of breeding conditions. In herds with low production levels, the best efficiency was achieved by cows that produced $6001-7000 \mathrm{~kg}$ milk as first calvers, while reduced lifetime milk yield and fertility were expected for higher yielding first calvers. In herds medium and high production levels, lifetime milk yield of the cows increased with increasing first lactation milk yield, while fertility deteriorated.

Table 2

Coefficients of correlation between first lactation milk yield and parameters of lifetime efficiency Korrelationskoeffizient für Beziehungen zwischen Erstlaktationsleistung und Parametern der Lebensleistung

\begin{tabular}{llc}
\hline & Correlated traits & Coefficient of correlation \\
\cline { 2 - 3 } First lactation milk yield & Lifetime yield (kg milk) & $0.452^{* *}$ \\
(kg milk) & Lifetime (years) & $0.226^{* *}$ \\
& Length of productive life (years) & $0.227^{* *}$ \\
& Length of productive life to life span (\%) & $0.216^{* *}$ \\
& Yield per day of life (kg milk) & $0.625^{* *}$ \\
& Yield per day of utilization (kg milk) & $0.615^{* *}$ \\
& Number of calvings & $0.100^{* *}$ \\
\hline
\end{tabular}

** significant at $P \leq 0.01$

Table 3

Proportion of cows according to first lactation milk yield and level of milk yield in the herd Proportion der Kühe nach Erstlaktations- und Herdenleistung

\begin{tabular}{lcccccc}
\hline $\begin{array}{l}\text { Herd yield level } \\
\text { (kg milk) }\end{array}$ & $\begin{array}{c}\text { Numbers } \\
\text { of cows }\end{array}$ & Percentage & \multicolumn{4}{c}{$\begin{array}{c}\text { Proportion of cows according to first lactation milk } \\
\text { yield (thousand kg of milk) } \chi^{2}=2537^{* *}\end{array}$} \\
\hline$\leq 5000$ & 2539 & 36.37 & 75.94 & 15.28 & 5.24 & $6-7$ \\
\hline $5001-6500$ & 2854 & 40.88 & 42.75 & 27.54 & 15.42 & 14.30 \\
$>6500$ & 1588 & 22.75 & 11.90 & 13.60 & 21.10 & 53.40 \\
Total number of cows & 6981 & 100.00 & 47.80 & 19.91 & 13.01 & 19.28 \\
\hline
\end{tabular}

** significant at $P \leq 0.01$

\section{References}

Baumung R, Sölkner J, Gierzinger E, Willam A (2001) Ecological total merit index for an Austrian dual purpose cattle breed. Arch Tierz 44, 5-13

Bielfeld J Ch, Badertscher R, Tölle K, Krieter J (2004) Influence of systematic effects on fertility traits in Swiss Brown cows. Arch Tierz 47, 537-49

Brzozowski P, Empel W, Zdziarski K, Grodzki H (2003) Influence of cows' health and their milk yield during first lactation on their productive life and life-time milk yield. Polish Vet Med 59, 626-29 [in Polish]

Dorynek Z, Pytlewski J, Antkowiak I (2006) Productive life and lifetime productivity of black-and-white cows kept in the loose barn system. Acta Sci Polon Zoot 5,13-24 [in Polish]

Dunklee JS, Freeman AE, Kelley DH (1994) Comparison of Holsteins selected for high and average milk production. 2. Health and reproductive response to selection for milk. J Dairy Sci 77, 3683-90

Freyer G, Erhardt G (2000) First results of a MAS study in dairy cattle with respect to longevity. Arch Tierz 43, 241-47

Gnyp J, Małyska T, Kamieniecki K, Kowalski P (1999) Effect of milk yield of Black-and-White primiparas on their milk performance fertility and utilization lenght in successive years. App Sci Rep Polish Soc Anim Prod 44, 117-23 [in Polish] 
Harder B, Junge W, Bennewitz J, Kalm E (2004) Investigations on breeding plans for organic dairy cattle. Arch Tierz 47, 129-39

Hinrichs D, Stamer E, Junge W, Kalm E (2006) Genetic analysis of several disease categories using test day threshold models in German Holstein cows. Arch Tierz 49, 3-16

Januś E, Borkowska D (2004) Relationship between milk yield in the first lactation and the indices of production traits fertility performance length and the reasons for culling cows. App Sci Rep Polish Soc Anim Prod 74, 103-9 [in Polish]

Juszczak J, Hibner A, Zachwieja A, Tomaszewski A, Krzyśków S (1994) Issue of high milk efficiencies. Anim Prod Rev 4, 3-5

Kancer FHJ, Mostert BE, Theron HE (2001) The effect of calving season and age at calving on production traits of South African dairy cattle. South Afr J Anim Sci 31, 205-14

Nebel Rl, Mcgilliard MI (1993) Interactions of high milk yield and reproductive performance in dairy cows. J Dairy Sci 76, 3257-68

Ouweltjes W, Smolders EAA, Eldik P, Elving L, Schukken YH (1996) Herd fertility parameters in relation to milk production in dairy cattle. Livest Prod Sci 46, 221-27

Reklewski Z, Łukaszewicz M, Dymnicki E, Oprzadek J (2004) Genetic quality of dairy cows vs culling reasons. Pr Mar Zoot 61, 45-57

SAS Institute Inc (2004) SAS/STAT(r) 91 User's Guide Cary NC SAS Institute Inc

Sawa A (1998) Genetic and environmental effects upon dairy cows performance in particular life periods. postdoctoral dissertation. Appl Sci Rep of University of Technology and Life Sciences in Bydgoszcz, Poland [in Polish]

Seeland G, Henze C (2003) Relations between milk yield and fertility after strong increased milk yield. Arch Tierz 46, 103-12 [in German]

Sölkner J, Miesenberger J, Willam A, Fuerst C, Baumung R (2000) Total merit indices in dual purpose cattle. Arch Tierz 43, 597-608

Swalve HH (2003) New breeding approaches for functional traits. Arch Tierz 46 Special Issue, 63-71

Swanson LV (1989) Interaction of nutrition and reproduction. J Dairy Sci 72, 805-14

The results of milk recording in Poland in 1999 year. CSHZ Warsaw 2000 [in Polish]

The results of milk recording in Poland in 2006 year. PFHBIPM Warsaw 2007 [in Polish]

Ziemiński R, Hibner A (1991) Length of exploitation and life performance of crossbred cows HF Pokolenia $F_{1}$ and $R_{1}$. Polish Agricul Annual Ser B 107, $65-74$ [in Polish]

Received 29 February 2008, accepted 26 November 2008.

Corresponding author:

Prof.Dr. habil. ANNA SAWA

email: sawa@utp.edu.pl

Department of Cattle Breeding, Faculty of Animal Breeding and Biology, University of Technology and Life Sciences, Mazowiecka 28, 85-084 Bydgoszcz, Poland 